\title{
Impedance spectroscopy of composites based on porous silicon and silica aerogel for sensor applications
}

\author{
A.Yu.Karlash, G.V.Kuznetsov, Yu.S.Milovanov, V.A.Skryshevsky \\ Institute of High Technologies, National T. Shevchenko University of \\ Kyiv, 64 Volodymyrs'ka Str., 01601 Kyiv, Ukraine
}

Received September 26, 2012

\begin{abstract}
Electrophysical and optical properties of heterogeneous composite systems based on nanosilicon $(n c-\mathrm{Si})$ and silica aerogel $\left(\mathrm{SiO}_{x}\right)$ powders have been investigated using impedance spectroscopy and FTIR spectroscopy methods. In FTIR transmittance spectra the presence of vibration modes of hydroxyl groups covering the internal surface of $\mathrm{SiO}_{x}$ matrix as well as associated $\mathrm{Si}-\mathrm{OH}$ groups has been revealed that should determine the sensing behavior of considered composites mainly under water treating. Based on impedance measurements possible mechanisms of charge carrier transport have been proposed. It was shown that the main process in carrier transport of pressed $\mathrm{SiO}_{x} / n c-\mathrm{Si}$ composite structures is the percolation tunneling of charge carriers through the silicon nanoclusters system. The dynamic interaction of composite structures with water molecules and pure ethyl alcohol has been investigated. It was revealed that desorption kinetics of $\mathrm{SiO}_{x} / n c-\mathrm{Si}$

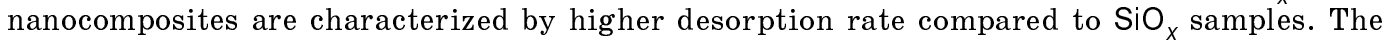
relative change of resistance value under water treating $\Delta R / R \cong 0.99$ was almost similar for all investigated samples that confirmed the crucial role of oxide matrix in adsorptiondesorption processes of considered composite structures. It was concluded that such sensing behavior could be utilized for construction the chemical sensors of humidity and alcohol based on porous $\mathrm{SiO}_{x}$ and $\mathrm{SiO}_{x} / n c-\mathrm{Si}$ nanocomposites.
\end{abstract}

Электрофизические и оптические свойства прессованых гетерогенных композитных систем на основе порошков нанокремния $n c-S i$ и аэрогеля кремнезема $\mathrm{SiO}_{x}$ исследованы методами импедансной спектроскопии и FTIR спектроскопии пропускания. В спектрах пропускания обнаружено наличие колебательных мод поверхностных гидроксильных групп и связанных $\mathrm{Si-OH}$ групп, которые определяют сенсорный отклик композитных систем на основе аэрогеля кремнезема преимущественно в водосодержащей среде. На основе измерений полного импеданса предложены возможные механизмы переноса заряда в прессованных нанокомпозитах, показано, что основным механизмом переноса в образцах $\mathrm{SiO}_{x} / n c-\mathrm{Si}$ является перколяционное тунеллирование через систему кремниевых нанокристаллитов. Исследование динамики взаимодействия композитных структур с молекулами воды и этилового спирта показало, что кинетика десорбции воды и спирта в образцах $\mathrm{SiO}_{x} / n c-\mathrm{Si}$ характеризуется большей скоростью десорбции по сравнению с образцами $\mathrm{SiO}_{x}$. Диапазон относительного изменения сопротивления во время обработки водой составлял $\Delta R / R \cong 0.99$ для обоих типов образцов, что подтверждает определяющую роль оксидной матрицы в адсорбционно-десорбционных процессах с участием композитных систем. Такие сенсорные характеристики открывают возможность использования пористых $\mathrm{SiO}_{x}$ и $\mathrm{SiO}_{x} / n c-\mathrm{Si}$ нанокомпозитов в качестве трансдьюсеров при создании химических сенсоров влаги и спирта. 


\section{Introduction}

Nanocomposite materials based on silicon nanocrystals embedded into the dielectric silicon oxide matrix have been intensively investigated for applications in different technical areas. It is considered that similar materials, possessing a large specific surface area, high porosity and fine grain structure, can be used as a comprehensive matrix for incorporation of nanoparticles and molecular adsorption in order to create the luminescent nanocomposites, photodetectors, catalysts, waveguides, lasers and gas sensors [1-5]. Taking into account the huge specific surface area and high porosity of $\mathrm{SiO}_{x}$ matrix it could easily absorb water as well as other polar molecules. The surface hydration effect causes the sensing behavior of silica aerogels and their composites when the adsorbates attach to the aerogel via hydroxyl groups.

It was shown [6] that nanosilicon in considered composites effectively reacts with an ambient environment. It's well known, that the hydrophilic oxygen terminated nanosilicon is more sensitive to water vapor than the original hydrogen-terminated porous silicon surface $[7,8]$. The effect of humidity on the conductivity of porous ceramics [9], porous silicon thin films [10] and other ceramic sensors mainly originated from the chemical and physical adsorption of water molecules existing in the sensor atmosphere [11]. However, the degradation process of nanosilicon based composites under aging at a humid atmosphere is under consideration today.

In a present work we have used the impedance spectroscopy method for investigation of pressed composite systems based on silica aerogel powder and nanosilicon powder embedded into $\mathrm{SiO}_{x}$ dielectric matrix. Possible mechanisms of charge carrier transport have been discussed too. The dynamic interaction of considered composite structures with deionized water and ethyl alcohol has been studied for sensor applications.

\section{Experimental}

The silica aerogel preparation method was based on the gradual water removing from the silicon acid gel. The silica gel, prepared from the sodium silicate water solution, was converted into an aerogel powder by a supercritical drying process [14, 15].
PS or nc-Si powder was produced by electrochemical etching of $\mathrm{p}-\mathrm{Si}$ plates in $\mathrm{HF}: \mathrm{C}_{2} \mathrm{H}_{5} \mathrm{OH}: \mathrm{H}_{2} \mathrm{O}$ electrolyte at constant current mode of $50 \mathrm{~mA} \cdot \mathrm{m}^{-2}$ during $2.5 \mathrm{~h}$. Porous powder was then rinsed in ethanol, dried in air and thoroughly grated. The final material was characterized to be the partially oxidized silicon nanocrystallites with the mean diameter of $3 \mathrm{~nm}$.

The samples for impedance investigations were prepared by pressing into pellets at a pressure of 133 bar the silica aerogel powder and mixture of silica aerogel with the $n c-S i$ powders in a composition 98:2. The mean diameter of pellets was about $12 \mathrm{~mm}$ and typical thickness $0.2 \omega 0.3 \mathrm{~mm}$. Pressed samples were then oxidized using UV irradiation during 2 h. For FTIR analyses samples were produced by pressing into pellets with the same parameters the mixture of $\mathrm{KBr}$ salt and composite powders.

The IR transmittance spectra were recorded by Perkin-Elmer Spectrum BXII FTIR spectrometer in the range 400$4000 \mathrm{~cm}^{-1}$ with spectral resolution $4 \mathrm{~cm}^{-1}$. Resulting FTIR spectra were corrected by $\mathrm{KBr}$ spectrum.

The impedance spectra were measured at $T=25^{\circ} \mathrm{C}$ using $\mathrm{Z}-2000$ impedance meter at an $a c$ current mode. Samples were held between two Pt-coated electrodes with the slight spring pressure, electrical contacts had an area of $10 \times 5 \mathrm{~mm}^{2}$. The investigation was performed at $a c$ frequencies $f$ in the range $(10 \mathrm{~Hz}-2 \mathrm{MHz})$. During measurements the $a c$ voltage amplitude was $100 \mathrm{mV}$, the error didn't exceed $5 \%$. For analyses of impedance spectra the model of successively connected parallel circuits has been considered and processing of experimental data have been done using ZView 2 program. The dynamic interaction of composite structures with water molecules and pure ethyl alcohol $\left(\mathrm{C}_{2} \mathrm{H}_{5} \mathrm{OH}, 96 \%\right)$ has been investigated by measuring the impedance hodographs under process of natural samples drying after treating.

\section{Results and discussion}

\subsection{FTIR transmittance spectroscopy}

Fig. 1 represents FTIR transmittance spectra of $\mathrm{SiO}_{x}$ (a) and $\mathrm{SiO}_{x} / n c-\mathrm{Si}$ (b) nanocomposites. The $\mathrm{SiO}_{x}$ spectrum shows absorption modes of stretching ( $\mathrm{LO}$ and $\mathrm{TO}$ ), bending and rocking vibrations of $\mathrm{Si}-\mathrm{O}-\mathrm{Si}$ bonds at 1187, 1095, 780 and $460 \mathrm{~cm}^{-1}$, 

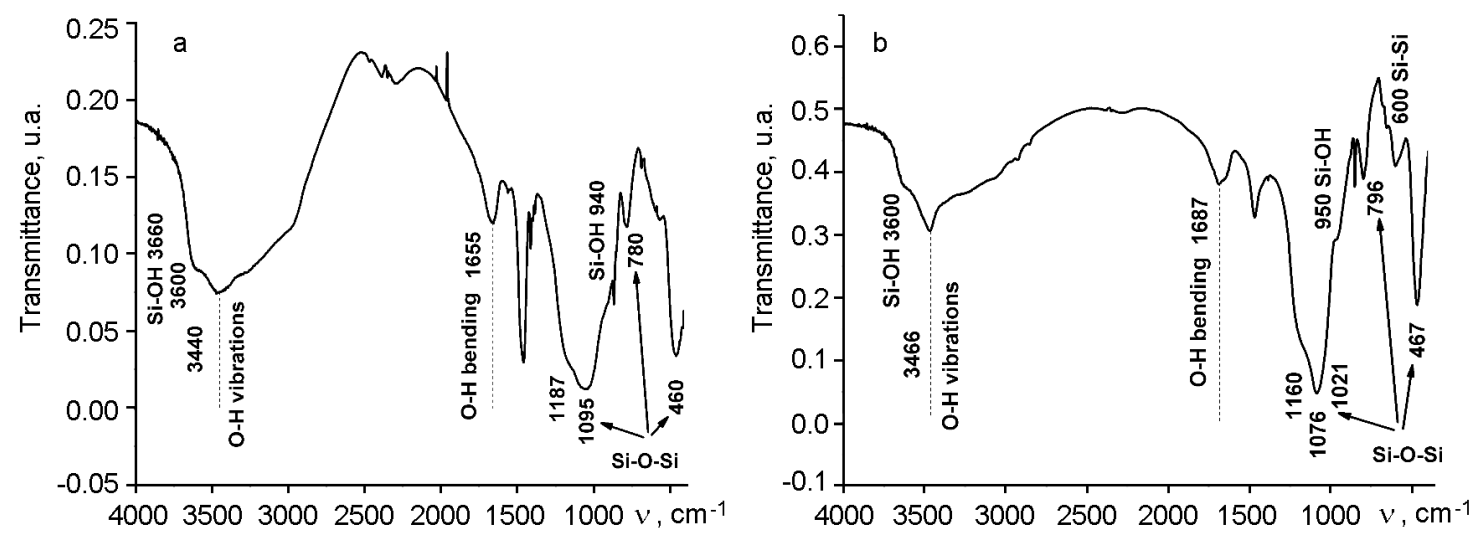

Fig. 1. FTIR transmittance spectra of $\mathrm{SiO}_{x}$ sample (a) and $\mathrm{SiO}_{x} / n c-\mathrm{Si}$ nanocomposite (b). Spectra were corrected by $\mathrm{KBr}$ spectrum.

respectively. The first two peaks are shifted from typical stoichiometric $\mathrm{SiO}_{2}[16,17]$ that may be caused by the non-stoichiometric structure of dielectric matrix. The strong absorption peak in $3000-3700 \mathrm{~cm}^{-1}$ region with a maximum at $3440 \mathrm{~cm}^{-1}$ is associated with vibrations modes of surface $\mathrm{OH}$ groups and adsorbed water. A weaker $\mathrm{O}-\mathrm{H}$ bending vibration band is revealed at $1655 \mathrm{~cm}^{-1}$.

During aging at a humid atmosphere the water absorption leads to breaking Si-O-Si bonds with creation of Si-OH groups [18, 19], in a FTIR spectrum of aerogel matrix shoulders at $3600 \mathrm{~cm}^{-1}$ and $940 \mathrm{~cm}^{-1}$ have been observed caused by associated $\mathrm{Si}-\mathrm{OH}$ vibration modes.

In the FTIR spectrum of $\mathrm{SiO}_{x} / n c-\mathrm{Si}$ nanocomposite (Fig. 1b) the presence of rocking $\left(467 \mathrm{~cm}^{-1}\right)$, bending $\left(796 \mathrm{~cm}^{-1}\right)$ and stretching LO $\left(1160 \mathrm{~cm}^{-1}\right)$ and TO $\left(1076 \mathrm{~cm}^{-1}\right)$ bands of silicon oxide have been revealed. Keeping at ambient conditions even for a short time leads to partial oxidation of silicon nanocrystals, that's why we almost don't observe the presence of Si$\mathrm{H}$ groups in the FTIR spectrum of $\mathrm{SiO}_{x} / n c-$ Si sample. The absorption peak at $600 \mathrm{~cm}^{-1}$ corresponds to volume $\mathrm{Si}-\mathrm{Si}$ bonds in silicon nanocrustallites. For $\mathrm{SiO}_{\chi} / n c-\mathrm{Si}$ sample the contribution of adsorbed water and surface $\mathrm{OH}$ groups have also been revealed in the spectral region of $3000-3700 \mathrm{~cm}^{-1}$ with maximum at $3466 \mathrm{~cm}^{-1}(\mathrm{O}-\mathrm{H}$ stretching vibrations modes and adsorbed water) and at $1687 \mathrm{~cm}^{-1}$ (O-H bending vibrations modes). Two shoulders at 3600 and $950 \mathrm{~cm}^{-1}$ associated with $\mathrm{Si}-\mathrm{OH}$ vibration modes.

The narrow peak at $1465 \mathrm{~cm}^{-1}$ in both spectra appears due to presence of sodium sili-

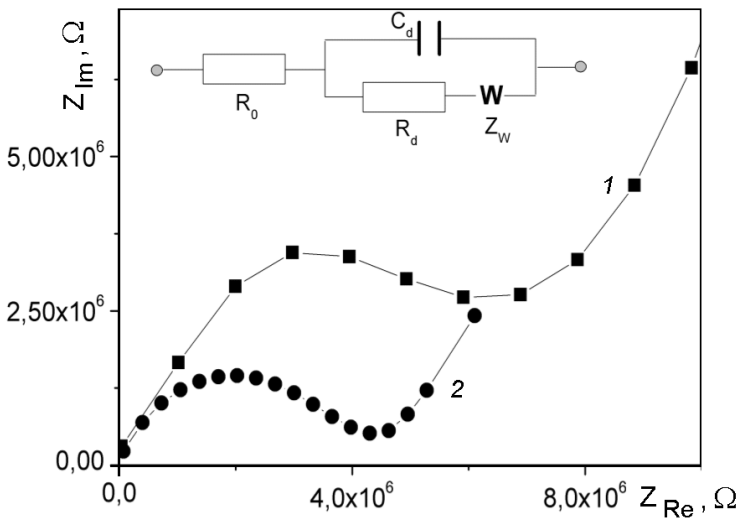

Fig. 2. Impedance hodographs of $\mathrm{SiO}_{x}$ sample: 1 - freshly prepared and 2 - aged during 30 days after water treating. Inset shows equivalent scheme of $\mathrm{SiO}_{x}$ structure.

cate in water solution used for aerogel preparing [15].

As a result, the FTIR transmittance spectra revealed that in the considered aerogel processing from water solution the internal surface of $\mathrm{SiO}_{x}$ and $\mathrm{SiO}_{X} / n c-\mathrm{Si}$ nanocomposites is almost covered with hydroxyl groups, that play the dominant role in the oxidation mechanism causing essential acceleration of the oxidation processes at a humid atmosphere.

\subsection{Impedance spectroscopy}

The typical impedance spectra in a Nyquist coordinates are presented on Fig. 2 for $\mathrm{SiO}_{x}$ sample. Only the one semicircle at a high-frequency region is observed, so it's difficult to distinguish the contribution from volume and boundary components in a total conductivity. At a low-frequency region the impedance hodograph appears to be 
a line with a slope of $45^{\circ}$ that is usually associated with the particle diffusion at interface boundary $[12,13]$.

The obtained dependences could be well described using equivalent scheme (inset on Fig. 2) that consists of the contact resistance $R_{0}$ connected with a parallel circuit. The last one consists of the total conductance $C_{d}$ and resistance $R_{d}$ of volume and boundary fractions as well as Warburg element $W$ that describes diffusion processes [12]. For samples under investigation the contact resistance was shown to be negligible compared to the total sample resistance. The impedance of Warburg element is determined from the equation: $Z_{W}=(1-$ $j) \cdot W \cdot \omega^{1 / 2}$, where $W$ is the Warburg constant, that depends on particle concentration and diffusion coefficient. The total impedance of equivalent scheme is $Z(\omega)=Z^{\prime}-j Z^{\prime \prime}=R_{0}+\left[j \omega C_{d}+1 /\left(R_{d}+Z_{W}\right)\right]^{-1}$.

At a relatively low frequencies $(\omega \rightarrow 0)$ we can neglect the contribution of frequency parts that have the exponent more than $1 / 2$. Then we obtain: $Z^{\prime \prime}=2 W^{2} \cdot C_{d}-R_{0}-$ $R_{d}+Z^{\prime}$. This equation describes the line with a slope of $45^{\circ}$ that intersects $Z_{R e}$ axis at a point $\left(R_{0}+R_{d}-2 W^{2} \cdot C_{d} ; 0\right)$. At high frequency region $(\omega \rightarrow 0)$ the Warburg impedance became unimportant and we can neglect all parts that contain $\omega^{-1 / 2}$, the total impedance is $\left(Z^{\prime}-R_{0}-R_{d} / 2\right)^{2}+\left(Z^{\prime \prime}\right)^{2}=\left(R_{d} / 2\right)^{2}$. The last equation describes the circle centered at $\left(0 ; R_{0}+R_{d} / 2\right)$ having a radius of $R_{d} / 2$. We obtained the numerical data on resistance $R=R_{0}+R_{d}$ of composite structure from the circle intersection with $Z_{R e}$ axis.

The ceramic materials based on $\mathrm{SiO}_{x}$ are considered to be heterogeneous two-phase system that consists of initial (volume) and intergrain phases. In the simplest case the sample contains isolated monocrystalline grains, connected by the interface boundaries with properties that differ from volume fraction. For description of $\mathrm{SiO}_{x}$ composite's properties the following model has been suggested: intergrain boundaries form persistent network surrounding isolated crystallites. The measured impedance hodographs (Fig. 2) indicate the presence of different conductivity mechanisms, namely the electron transport in a grain volume and through the intercrystallite boundaries as well as the diffusive proton transport in a surface layer of hydrated silicon oxide.

The $\mathrm{SiO}_{x}$ surface has been observed to demonstrate the high proton-donor ability. The adsorbed water molecules form com-

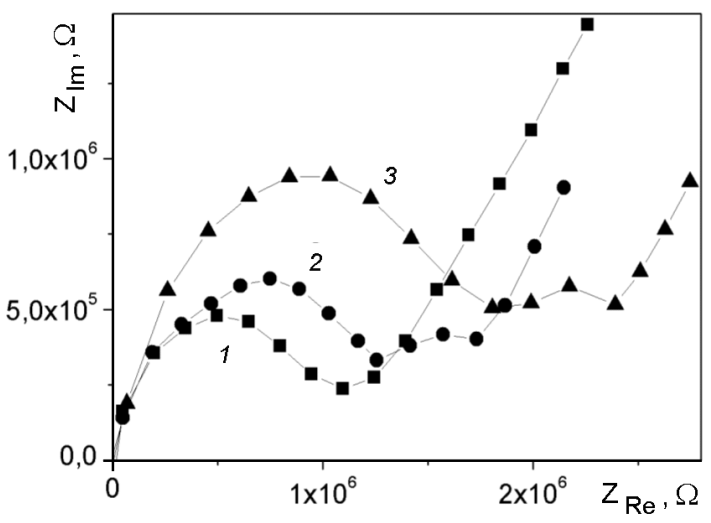

Fig. 3. Impedance hodographs of $\mathrm{SiO}_{x} / n c-\mathrm{Si}$ nanocomposite: 1 - freshly prepared and aged after water treating under ambient conditions during: $2-7$ days, $3-30$ days.

plexes connected with $\mathrm{Si}-\mathrm{OH}$ groups by hydrogen bonds $[19,20]$. These complexes can dissociate forming free $\mathrm{H}_{3} \mathrm{O}^{+}$molecules and bounded $\mathrm{Si}_{-} \mathrm{O}^{-}$groups according to the scheme: $\mathrm{Si}-\mathrm{OH} . . . \mathrm{OH}_{2} \rightarrow \mathrm{Si}-\mathrm{O}^{-}+\mathrm{H}^{+}: \mathrm{H}_{2} \mathrm{O}$. In this case proton having high mobility can be trapped by a neighbor $\mathrm{H}_{2} \mathrm{O}$ molecule: $\mathrm{H}_{2} \mathrm{O}_{(1)}: \mathrm{H}^{+}+\mathrm{H}_{2} \mathrm{O}_{(2)} \rightarrow \quad \mathrm{H}_{2} \mathrm{O}_{(1)}+\mathrm{H}^{+}+\mathrm{H}_{2} \mathrm{O}_{(2)}$ $\rightarrow \mathrm{H}_{2} \mathrm{O}_{(1)}+\mathrm{H}^{+}: \mathrm{H}_{2} \mathrm{O}_{(2)}$.

The considered mechanism allows the implementation of proton transport through the intergrain layer of $\mathrm{SiO}_{x}$ matrix. In addition to above process there is a collective proton conductivity caused by associated Si$\mathrm{OH}$ groups [19, 21].

During sample aging at ambient atmosphere the effect of surface hydratation by adsorbed water strongly intensified causing the decrease of resistance of the intercrystallite layer and composite structure on a whole (curve 2 on Fig. 2).

Fig. 3 shows the impedance hodograph of $\mathrm{SiO}_{x} / n C-\mathrm{Si}$ nanocomposite freshly prepared (curve 1) and dried after water treating (curves 2 and 3). As one can see, freshly prepared $\mathrm{SiO}_{x} / n c-\mathrm{Si}$ samples are characterized by much more low resistance values $\left(R \simeq 10^{6} \Omega\right)$ compared to $\mathrm{SiO}_{x}$ structure $\left(R \simeq 10^{7} \Omega\right.$ ). It may be caused by processes of percolation tunneling of charge carriers through the system of low-resistance silicon nanoclusters [21, 22].

In $\mathrm{SiO}_{x} / n c-\mathrm{Si}$ composite structures the impedance of elementary conducting cluster "Si grain - $\mathrm{SiO}_{x}$ spacer - Si grain" is characterized by parallel $R_{c l} C_{c l}$ circuit of silicon particle connected with a parallel $R_{d l} C_{d l}$ circuit of the $\mathrm{SiO}_{x}$ dielectric spacer. The total impedance of the composite can be obtained by summing the impedances of 

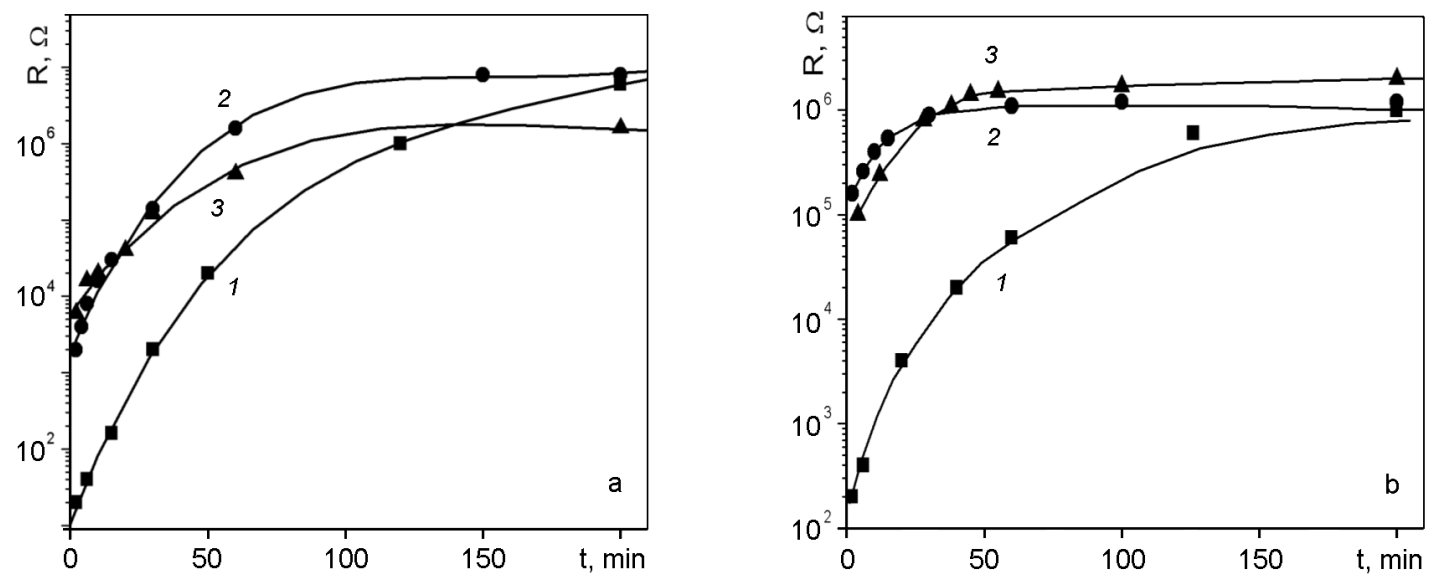

Fig. 4. The time dependences of resistance of $\mathrm{SiO}_{x}$ (a) and $\mathrm{SiO}_{2} / n c-\mathrm{Si}$ (b) structures under desorption of $\mathrm{H}_{2} \mathrm{O}(1)$ and ethyl alcohol $\left(\mathrm{C}_{2} \mathrm{H}_{5} \mathrm{OH}\right)(2,3)$. 1, 2 - freshly prepared samples; 3 - repeated measurements.

structural units of the conducting clusters. Owing to the random spacing of silicon nanoparticles over the volume of dielectric matrix their resistance and capacitance appear to be accidental. As a result the composite contains a set of microscopic relaxators - $R_{d l} C_{d l}$ circuits - that are characterized by different time constants. In the equivalent scheme it's accounted through replacement the capacitance $C_{d}$ by constant phase element (CPE) [12]. At high frequencies, when the electrical resistance of spacers is shunted by their capacitance, the real part of impedance is determined by the electrical resistance of silicon nanoparticles. At low frequencies the effective electrical conductivity of considered nanocomposites is determined by $\mathrm{SiO}_{x}$ spacers and accordingly the proton transport mechanism by analogy with pressed $\mathrm{SiO}_{x}$ composites.

Unlike the $\mathrm{SiO}_{x}$ structures, in composite $\mathrm{SiO}_{x} / n c-\mathrm{Si}$ materials the prolonged aging at ambient atmosphere results in increasing of resistance. In experimental hodographs (Fig. 3, curves 2, 3) three characteristic areas were observed: the semicircle of higher radius, that can be extrapolated to zero point; the part of semicircle with lower radius (poor distinguished) and the line at low frequencies with a slope of $45^{\circ}$. The high-frequency semicircle usually attributed to the volume conductivity and, therefore, its diameter lets obtain the material resistance without the contact resistance value. The low-frequency semicircle corresponds to carrier transport through the grain boundaries. The strong deformation of the low-frequency semicircle is caused by the absence of a certain characteristic relaxation time due to inhomogeneity of the intergrain boundary properties. Under aging process the low-frequency range became more stipulated that is caused by increasing the impact of oxide layer and possible formation of $\mathrm{SiO}_{x} / n c-\mathrm{Si}$ interface.

The dynamic interaction of composite structures with water molecules and pure ethyl alcohol $\left(\mathrm{C}_{2} \mathrm{H}_{5} \mathrm{OH}, 96 \%\right)$ has been investigated by measuring the impedance hodographs under process of natural drying after treating. The experimental dependences of sample resistance as a function of desorption time have been obtained based on impedance spectra. Fig. $4 a$ presents the calculated $R(t)$ dependences under $\mathrm{H}_{2} \mathrm{O}$ and $\mathrm{C}_{2} \mathrm{H}_{5} \mathrm{OH}$ desorption for $\mathrm{SiO}_{x}$ sample. The maximum sensor response $S_{m}=R$ (air) $/ R$ (water) $\mid$ is equal to $3 \cdot 10^{5}$ in the case of water treating and $3 \cdot 10^{2}$ for alcohol treating. These values are essentially higher than similar parameters of traditional porous materials used for sensor applications [23-26].

Adsorbed water molecules can form the continuous polymolecular layer on a surface of hydrated oxide causing the proton carrier transport. Under complete filling of micropores by condensate the proton carrier transport trough the network of hydrogenbonded molecules appears without participation of porous solid matrix. Therefore, at the first moment after water absorption the resistance of composite structure drastically decreases. At the same time, the surface $\mathrm{OH}$ groups are very unstable and easily destroyed under water desorption process, that's accompanied by gradual increasing of the sample resistance (Fig. 4a, curve 1). The process under $\mathrm{C}_{2} \mathrm{H}_{5} \mathrm{OH}$ desorption is faster compared to $\mathrm{H}_{2} \mathrm{O}$ treating and the dynamic 
range is decreased (curve 2, Fig. 4b). Obviously, it is stipulated by the less effective hydratation process of $\mathrm{SiO}_{x}$ surface. As a result of sample treating the part of adsorbed molecules turn from capillary-condensed state into the more stable bounded state and this leads to increase of sample resistance and lowering of dynamic range at repeated measurements compared to freshly prepared structure (Fig. 4a, curve 3).

The calculated $R(t)$ dependencies for $\mathrm{SiO}_{x} / n c-\mathrm{Si}$ composites are shown on Fig. $4 \mathrm{~b}$. It's clearly seen that under water desorption the sample resistance increases from $200 \Omega$ immediately after water adsorption to $1.3 \mathrm{M} \Omega$ for dried materials, maximum sensor response is $S_{m}=6 \cdot 10^{3}$. During ethyl alcohol desorption the dynamic range is much lower (by $10^{3}$ times) for initial sample (curve 2, Fig. 4b) and rather increases at repeated measurements (curve 3, Fig. 4b). The desorption kinetics of $\mathrm{SiO}_{x} / n c-\mathrm{Si}$ nanocomposites under water and alcohol treating are characterized by higher desorption rate compared to $\mathrm{SiO}_{x}$ samples. Simultaneously additional hydratation process under water treating has been obtained to improve the sensibility of considered nanocomposite. It should be pointed out that the $\Delta R / R$ value was almost similar for all investigated samples that confirm the crucial role of oxide matrix in adsorption-desorption processes of considered composite structures. We think that such sensing behavior could be utilized for construction of chemical sensors based on porous $\mathrm{SiO}_{x}$ and $\mathrm{SiO}_{x} / n c-\mathrm{Si}$ nanocomposites.

\section{Conclusions}

Electrophysical and optical properties of heterogeneous composite systems based on nanosilicon $n c-S i$ and silica aerogel matrix $\mathrm{SiO}_{x}$ have been investigated using impedance spectroscopy and FTIR spectroscopy methods. In FTIR transmittance spectra the presence of vibration modes of hydroxyl groups covering the internal surface of $\mathrm{SiO}_{x}$ matrix as well as associated $\mathrm{Si}-\mathrm{OH}$ groups has been revealed. It was considered that hydroxyl groups play the dominant role causing essential acceleration of the oxidation processes at a humid atmosphere.

From impedance measurements it was obtained that the conductivity of $\mathrm{SiO}_{x}$ and $\mathrm{SiO}_{x} / n c-\mathrm{Si}$ composites is characterized by proton and electron components. It was shown that the main process in pressed $\mathrm{SiO}_{x} / n c-\mathrm{Si}$ composite structures is the per- colation tunneling of charge carriers through the silicon nanoclusters system. The $\mathrm{SiO}_{x}$ surface has been observed to demonstrate the high proton-donor ability that allows implementation of proton transport through the intergrain layer of $\mathrm{SiO}_{x}$ matrix. After water treating the effect of surface hydratation by water vapor was shown to strongly intensify causing the decrease of resistance of the intercrystallite layer and composite structure on a whole. Unlike the $\mathrm{SiO}_{x}$ structures in composite $\mathrm{SiO}_{x} / n c-\mathrm{Si}$ materials the prolonged aging at ambient atmosphere results in increasing of resistance that is caused by increasing the impact of oxide layer and possible formation of $\mathrm{SiO}_{x} / n c-\mathrm{Si}$ interface

The dynamic interaction of composite structures with water molecules and pure ethyl alcohol $\left(\mathrm{C}_{2} \mathrm{H}_{5} \mathrm{OH}, 96 \%\right)$ has been investigated. It was obtained that considered composite structures are characterized by higher maximum sensor responses and desorption rates compared to traditional porous materials for sensor applications. Simultaneously additional oxidation process under water treating has been obtained to improve the sensibility of $\mathrm{SiO}_{x} / n c-\mathrm{Si}$ nanocomposite compared to $\mathrm{SiO}_{x}$ structures.

Acknowledgements. The work has been funded in part by the State Agency for Science, Innovation, and Information of Ukraine (project No.F40.7/15).

\section{References}

1. C.C.Koch, Nanostructured Materials: Processing, Properties and Applications, William Andrew Inc, Norwich, NY (2007).

2. X.X.Wang, J.G.Zhang, L.Ding et al., Phys. Rev. B, 72, 195313 (2005).

3. K.Seino, F.Bechstedt, P.Kroll, Nanotechnology, 20, 135702 (2009).

4. I.V.Antonova, V.A.Skuratov, J.Jedrzejewski et al., Semiconductors, 44, 501 (2010).

5. A.Yu.Karlach, G.V.Kuznetsov, S.V.Litvinenko et al., Semiconductors, 44, 1387 (2010).

6. G.Cantele, E.Degoli, E.Luppi et al., Phys. Stat. Solidi C, 2, 3263 (2005).

7. J.M.Lauerhaas, M.J.Sailor, Science, 261, 1567 (1993).

8. E.J.Lee, J.S.Ha, M.J.Sailor, Mat.Res.Soc. Symp. Proc., 358, 358 (1995).

9. E.Traversa, Sensor.Actuator. B, 23, 135 (1995).

10. C.-T.Wang, C.-L.Wu, Thin Solid Films, 496, 658 (2006).

11. P.M.Faia, C.S.Furtado, A.J.Ferreira, Sensor. Actuator. B, 107, 353 (2005). 
12. E.Barsoukov, Impedance Spectroscopy: Theory, Experiment, and Applications, Macdonald J.R. Willey: N.Y. (2005).

13. A.J.Bard, L.R.Faulkner, Electrochemical Methods. Fundamentals and Applications, Willey: N.Y. (2001).

14. M.R.Ayers, A.J.Hunt, J.Non-Cryst.Solids, 285, 123 (2001).

15. A.Yu.Karlash, G.V.Kuznetsov, V.A.Skryshevsky et al., J.Phys. D: Appl. Phys., 43, 335405 (2010).

16. S.Litvinenko, E.Garrone, D.Barbier et al., Intern. J. Hydrogen Energy, 35, 6773 (2010).

17. V.P.Tolstoy, I.V.Chernyshova, V.A.Skryshevsky. Handbook of Infrared Spectroscopy of Ultrathin Films, Willey: N.Y. (2003).

18. B.Stuart, Infrared Spectroscopy: Fundamentals and Applications. Willey: N.Y. (2004).
19. M.Nogami, R.Nagao, Cong Wong, J.Phys. Chem. B, 102, 5772 (1998).

20. Chao Cao, Yao He, J.Torras et al., J.Chem. Phys., 126, 211 (2007).

21. N.N. Kononov, S.G. Dorofeev, A.A.Ishchenko et al., Semiconductors, 45, 1068 (2011).

22. N.A.Poklonski, N.I.Gorbachuk, D.Aleinikova, Phys. Solid State, 53, 462 (2011).

23. R.J.Mortimer, R.J.Mayers, Sensor.Actuator. $B, 128,24$ (2007).

24. K.M.S.Khalil, S.A.Makhlouf, Sensor.Actuator. $A, 148,39$ (2008).

25. G.Di Francia, A.Castaldo, E.Massera et al., Sensor. Actuator. B, 111-112, 135 (2004).

26. V.A.Moshnicov, I.Gracheva, A.S.Lenshin et al., J.Non-Cryst. Solids, 358, 590 (2012).

\title{
Імпедансна спектроскопія композитів на основі поруватого кремнію та аерогелю кремнезему для використання у сенсориці
}

\author{
А.Ю.Карлаш, Г.В.Кузнєцов, Ю.С.Мілованов, \\ В.А.Скришевський
}

\begin{abstract}
Електрофізичні та оптичні властивості гетерогенних композитних систем на основі нанокремнію nc-Si та аерогелю кремнезему $\mathrm{SiO}_{x}$ досліджено методами імпедансної спектроскопії та FTIR спектроскопії пропускання. Спектри пропускання виявили наявність коливальних мод поверхневих гідроксильних груп та зв'язаних Si-OH груп, які обумовлюють сенсорну поведінку досліджуваних композитних систем переважно у водовмісному середовищі. На основі вимірювань повного імпедансу запропоновано можливі механізми переносу заряду у пресованих нанокомпозитах, показано, що основним механізмом переносу заряду у зразках $\mathrm{SiO}_{x} / n c-\mathrm{Si}$ e перколяційне тунелювання через систему кремнієвих нанокристалітів. Дослідження динаміки взаємодії композитних структур з молекулами води та етилового спирту виявили, що кінетика десорбції води та спирту у нанокомпозитах $\mathrm{SiO}_{x} / n c-\mathrm{Si}$ характеризується більшою швидкістю десорбції порівняно зі зразками $\mathrm{SiO}_{x}$. Діапазон відносної зміни опору під час обробки водою становив $\Delta R / R \cong 0.99$ для обох типів зразків, що підтверджує визначальну роль оксидної матриці в адсорбційно-десорбційних процесах за участю композитних систем. Такі сенсорні характеристики відкривають можливість використання поруватих $\mathrm{SiO}_{x}$ та $\mathrm{SiO}_{x} / n c-\mathrm{Si}$ нанокомпозитов у якості трансд'юсерів при створенні хімічних сенсорів, вологи та спирту.
\end{abstract}

